\title{
Katerina Pishchikova, Promoting Democracy in Postcommunist Ukraine: The Contradictory Outcomes of US Aid to Women's NGOs
}

\author{
FirstForumPress, Boulder \& London, 2011, 237 pp., USD \$65.00 \\ (hardcover)
}

\author{
Mónica Lopes
}

Published online: 14 August 2012

(C) International Society for Third-Sector Research and The John's Hopkins University 2012

The collapse of communism coincided with a paradigm shift in the logic of international aid, in which NGOs are regarded as key channels for assistance. Civil society is now considered crucial to the post-communist political transformation and a panacea for problems from corruption and lack of accountability to service delivery needs. However, some analysts have started to criticize this vision of civil society and the civil society development approach adopted by international organizations in these countries.

In her eloquent and critical book, Kateryna Pishchikova fuels the discussion about the impact of external assistance programs for promotion of democracy in recipient countries focusing on the case of Ukraine. Through a constructivistinterpretive approach, the author aims to unveil the fundamental aspects of the assistance logic that considers development aid as a political process of great significance at a global scale. She does this by analyzing "the different meanings of foreign assistance to civil society that are created, translated or (re)enacted in different contexts, where donors and aid recipients interact, directly or indirectly" (p. 4).

Bearing in mind, the discrepancy between the USAID's programs self-described as designed to promote comprehensive and lasting democratic change, and the insights of Ukrainian women NGOs, to whom these funds are but personal sources of income for individuals who have learned to speak the language of donors, the author asks: "Are donors blind or do they just not care? Are locals wicked or just plain stupid"? (p. 2).

Pishchikova answers these questions in the eight well-organized chapters of the book. The reasons, objectives, and the theoretical and methodological purposes of

Book Review Editor: Silvia Ferreira

M. Lopes ( $\square)$

Centro de Estudos Sociais da Universidade de Coimbra, Coimbra, Portugal

e-mail: monica@ces.uc.pt 
the book are clarified in the Introduction and the main subjects are explored and discussed in chapters 2 to 4, where the framework of the empirical analysis is provided.

Filling in the dearth in the studies of many Western authors, Pishchikova chooses to give voice to Eastern European scholars and their conceptualizations of civil society and gender, presenting a wide range of local ideas about the meaning of the public sphere, individual and collective activism and the role of civil society in the state. In chapters 5, 6, and 7 the author describes the empirical analysis, based on an extensive set of interviews and documents gathered in the field work in three core interaction sites (Washington, DC-donors; Kiev-mediators of assistance; and local Ukrainian NGOs-assistance recipients). In these chapters, many of the assertions about the logics and practices of democracy promotion and support to civil society explored in the theoretical chapters are resumed and reinforced.

The concluding chapter compares the discursive logics around assistance to civil society in the three core interaction sites. In a detailed analysis of the origins and implementation of assistance in Ukraine, Pishchikova argues that its central concepts and principles are defined in Washington, DC, reinterpreted in Kiev and misunderstood or undermined locally.

Right from the Introduction, the author presents some of her conclusions, disclosing that the "understanding of assistance as a top-down transfer of technical expertise has inspired the creation of particular forms of local civic activism and promoted narrowly defined and essentially disempowering practices of women empowerment and capacity building of local civic activism"(p. 8). Women's NGOs and gender discourse appear in the book as a corollary of these kind of top-down interactions, marked by different perceptions, priorities, and agendas. She argues, nonetheless, that assistance cannot be seen as simple hegemony imposed from outside, since it is made possible through the interactions between Americans and Ukrainians. In fact, despite the different understandings of the meaning of gender and assistance to civil society, the core of the assistance discourse remains intact in the three sites of interaction. Pishchikova concludes that the dominance of the discourse on civil society assistance entails more negative than positive effects, because it "falls short of the proclaimed goal of democracy-building, and impedes the development of indigenous civil society" (p. 198).

Although some of the objectives and topics of this book are covered in other studies, the analysis of development discourse and its local readings translate into a narrative consistent and well justified by the different perspectives of the various stakeholders. However it is unclear, the extent to which the divergent understandings about health, civil society, and empowerment of women turn into different program implementation practices, whose analysis would be useful for a better understanding of their impacts. Given the empirical focus, a specific look at possible variations in conceptualizing "assistance to women's NGOs" by the USAID and Ukrainian stakeholders could also add to the interest of the book. Furthermore, since the author concludes that Western assistance leads to NGOs' investment in unsustainable activities unrelated to the democratic purposes of civil society, one could expect a larger space to be reserved for the debate about which activities and organizational forms can be realistically maintained beyond the assistance cycle. 
In any case, it is a book of exemplary clearness that articulates theoretical debates with important policy issues appealing both to scholars interested in gender policies, democratization, and civil society development in post-communist countries, and to policymakers, agencies and aid professionals. 